\title{
Assessing patterns of geographic dispersal of Gelidium sesquipedale (Rhodophyta) through RAPD differentiation of populations
}

\author{
Filipe Alberto $^{1}$, Rui Santos ${ }^{1, *}, J^{\prime}$ sé M. Leitão ${ }^{2}$ \\ ${ }^{1}$ Centro de Ciências do Mar (CCMAR) and ${ }^{2}$ Laboratório de Genética e Melhoramento, Universidade do Algarve, \\ Campus de Gambelas, 8000 Faro, Portugal
}

\begin{abstract}
Randomly amplified polymorphic DNAs (RAPDs) of bulked genomic DNA samples were used to analyse the genetic differentiation of Gelidium sesquipedale populations. They reflect the patterns of gene flow, which in turn depend on the dispersal mechanisms of the species and on near-shore ocean currents. Fourteen populations were sampled from northern France to Morocco, covering the geographical distribution of the species. A single bulk DNA sample (from 15 individuals) was used in each population, under the assumption that the resulting patterns represent the populations' most common genetic features. To test this, we investigated the genetic variability among 5 bulk samples within a single population. Genetic distances among bulks were very low (average $=0.065$ ) and were significantly lower than those observed between geographically separated populations (average $=0.241$ ) . Neighbour-joining analysis of the distance matrix of populations separated a well-supported group including populations of northern Spain and of northern France, and a less-supported group containing populations of northern Portugal. Multidimensional scaling of the genetic distance matrix revealed 2 isolated populations, Sāo Rafael in southern Portugal and Algeciras in southern Spain. These patterns of genetic differentiation are discussed under the available data on the near-shore ocean currents. Results suggest that the genetic differentiation of $G$. sesquipedale populations may be used as a biological tracer of prevailing flows and barriers of the near-shore currents. A positive correlation between geographical and genetic distances of $G$. sesquipedale populations along the species geographical distribution was found, suggesting that a continuous transport of detached fronds and their reattachment to new substrate must be an effective dispersal mechanism of the species, sustaining the gene flow among populations.
\end{abstract}

KEY WORDS: Gelidium sesquipedale - RAPD - Population genetic variability - Geographical and genetic distances - Seaweed dispersal - Northeast Atlantic circulation · Biotracers

\section{INTRODUCTION}

Gelidium sesquipedale populations can be found along exposed shores of the Northeast Atlantic from Cornwall, southwest of Great Britain, to Mauritania (Dixon \& Irvine 1977). The species is the most economically important agarophyte algae in the Northeast Atlantic, particularly in Spain, Portugal and Morocco (Juanes \& Borja 1991, Santos \& Duarte 1991, Melo 1998). It is the main source of raw material for specialised, highly priced products such as bacteriological grade agar and agarose.

\footnotetext{
•Corresponding author.E-mail: rosantos@mozart.si.ualg.pt
}

Here we assessed the patterns of genetic differentiation of populations of Gelidium sesquipedale along the species geographical distribution. They reflect the patterns of gene flow, which in turn depend on the dispersal mechanisms of the species and on near-shore ocean currents. As the most important mechanism of seaweed dispersal along the shores seems to be the transport of broken thalli by currents (see Santelices 1990 for a review), there must be a significant relationship between the genetic distances among populations and their geographical distances. The patterns of genetic differentiation of seaweed populations may be used as biotracers of prevailing flows and barriers of the poorly defined near-shore ocean currents. To our knowledge, 
seaweeds have never been used as biological tracers unlike oceanic planktonic species (Bucklin et al. 1989, Stoehr et al. 1997), fishes and invertebrates (Saavedra et al. 1995, Borsa et al. 1997).

To analyse the genetic differentiation of Gelidium sesquipedale populations we used randomly amplified polymorphic DNAs (RAPDs), a PCR technique developed by Welsh \& McClelland (1990) and Williams et al. (1990). It consists of the amplification of genomic DNA using short random primers and low annealing temperatures. The amplification products are separated by gel electrophoresis, and differences between genotypes are reflected as differences in the banding pattern. For a general review of this technique, see Weising et al. (1995). In seaweed studies, RAPDs have been used for species identification (Patwary et al. 1993, Dutcher \& Kapraun 1994, Patwary \& van der Meer 1994, Ho et al. 1995, Gonzalez et al. 1996, Meneses 1996), biogeographic studies (van Oppen et al. 1994. Pakker et al. 1996), and the determination of genetic relatedness among and within populations (Coyer et al. 1997). Van Oppen et al. (1996) assessed the limits of RAPDs for seaweed biogeography. They suggested that RAPD data are accurate in identifying populations at large spatial scales (hundreds to thousands of kilometres apart), but may fail at shorter geographical scales.

Bulk DNA samples of Gelidium sesquipedale populations were used in this work. A bulk sample can be conceived of as a sample of the population DNA (Yu \& Pauls 1993). These authors state that, although some genetic information is lost, RAPD patterns resulting from bulked-DNA samples represent a signature for the most common genetic features of the population. Michelmore et al. (1991) found that rare RAPD markers could not be detected in bulks when the DNA sample that they were derived from represented less than $10 \%$ of the total DNA. Bulk methodology proved to be adequate for assessing the genetic similarities between 3 G. sesquipedale populations from southern Portugal (Alberto et al. 1997). To assess if a single bulk sample represented the most common genetic features of a population we investigated the genetic variability among bulk samples of the same population.

\section{METHODS}

DNA extraction and bulking followed the procedures of Alberto et al. (1997). Fourteen populations were sampled, covering the species geographical distribution (Fig. 1). Fifteen tufts were collected in each population, except for Roscoff where only 5 tufts were collected. To make sure that each sample corresponded to a different individual, only 1 erect frond was sampled from each tuft (Alberto et al. 1997). Bulk variability at the population level was investigated by analysing the genetic distances among 5 bulk samples of Gelidium sesquipedale collected along a $2.5 \mathrm{~km}$ stretch of Cape Espichel coast (Portugal).

Samples were examined under a stereo microscope to select 15 vigorous, epiphyte-free fronds for DNA extraction. The apical portions of branches were cut and washed in a series of tap water and detergent (Teepol), in distilled water and in double-distilled sterile water. Population bulks were obtained by mixing $200 \mathrm{mg}$ (wet weight) of algal material from each individual in a large sterile mortar. The tissue was ground in liquid nitrogen using a pestle. All the powder within the mortar was collected into a $50 \mathrm{ml}$ polypropylene centrifuge tube (Nalgene cat-3119), ensuring that each individual contributed an equal amount of tissue to the final mixture. In each tube, $18 \mathrm{ml}$ of extraction buffer $(200 \mathrm{mM}$ Tris [pH 8.5], $250 \mathrm{mM} \mathrm{NaCl}, 25 \mathrm{mM}$ EDTA, 0.5\% SDS) was added. Samples were then gently mixed and incubated at $65^{\circ} \mathrm{C}$ for $30 \mathrm{~min}$. This buffer-heating step resulted in clearer DNA samples than those obtained in Alberto et al. (1997). A volume of $9 \mathrm{ml}$ of $3 \mathrm{M}$ sodium acetate was added. Samples were gently agitated, and

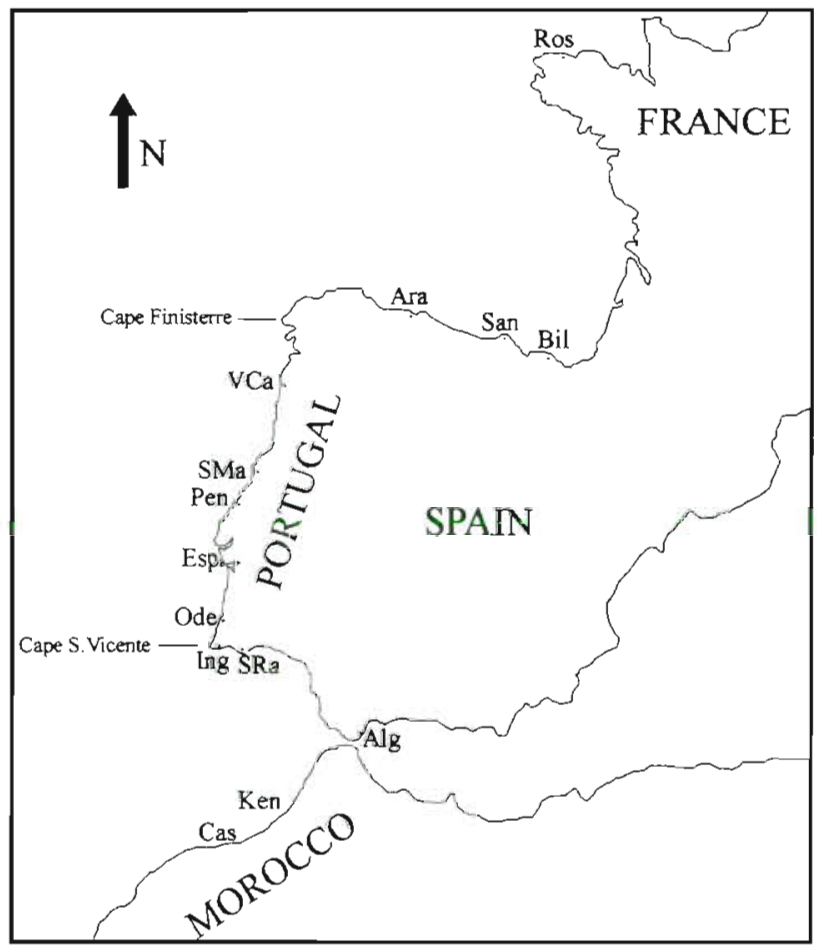

Fig. 1. Geographical location of Gelidium sesquipedale populations analysed in this study. Ros: Roscoff, Bil: Bilbao, San: Santander, Ara: Aramar, VCa: Viana do Castelo, SMa: São Martinho, Pen: Peniche, Esp: Espichel, Ode: Odeceixe, Ing: Ingrina, SRa: Sào Rafael, Alg: Algeciras, Ken: Kenitra, Cas: Casablanca 


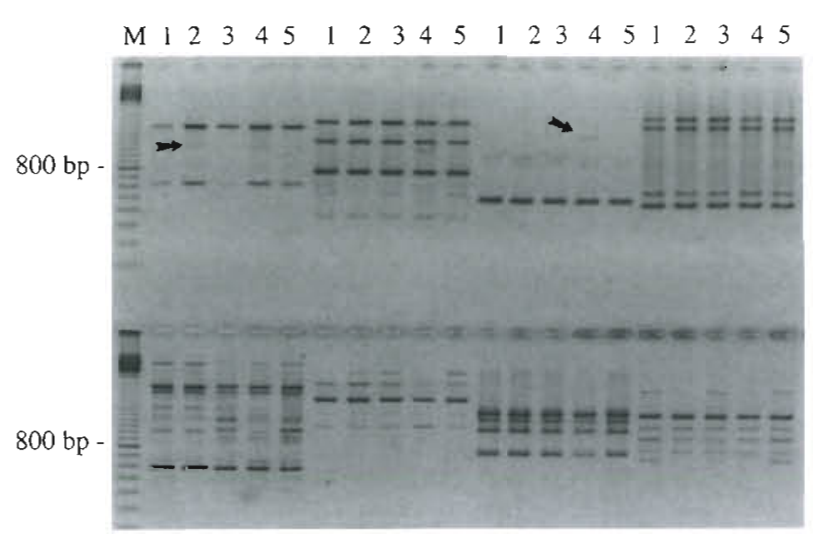

Fig. 2. RAPD amplifications of the 5 bulk samples of the Gelidium sesquipedale population of Espichel. Eight primers are presented: OPL13, OPL14, OPL15, OPL16, OPK4, OPK11, OPM5 and OPM6. Arrows indicate examples of 2 ambiguous bands. Lane $M$ is the 100 base pair ladder molecular size marker, the larger band is $800 \mathrm{bp}$

then incubated at $-20^{\circ} \mathrm{C}$ for $10 \mathrm{~min}$. The mixture was centrifuged at $14000 \times g$ for $10 \mathrm{~min}$. The supernatant was collected and precipitated with an equal volume of isopropanol (5 $\mathrm{min}$ at room temperature). The crude DNA extract was then centrifuged $(14000 \times g, 5 \mathrm{~min})$. The pellet was washed with ice cold $80 \%$ ethanol, centrifuged again $(14000 \times g, 5 \mathrm{~min})$, dried under vacuum and dissolved in $500 \mu \mathrm{l}$ of Tris EDTA (TE) buffer. The quality of the bulk DNA samples was determined by agarose gel electrophoresis, and concentrations were estimated by comparisons with known quantities of prepurified calf thymus DNA (Pharmacia) (Sambrook et al. 1989).

Amplifications were performed in a total volume of $25 \mu \mathrm{l}$ containing $2.5 \mu 10 \times \mathrm{Taq}$ DNA polymerase buffer $(100 \mathrm{mM}$ Tris $\mathrm{HCl}$, $\mathrm{pH}=9.0,500 \mathrm{mM} \mathrm{KCl}, 15 \mathrm{mM} \mathrm{MgCl}_{2}$ ), $150 \mu \mathrm{M}$ of each dATP, dGTP, dCTP, dTTP, $0.4 \mu \mathrm{M}$ of the primers, $20 \mathrm{ng}$ genomic DNA and 1 unit Taq DNA polymerase (Pharmacia Biotech). PCR amplifications were programmed for a denaturation cycle of $1.5 \mathrm{~min}$ at $94^{\circ} \mathrm{C}$ followed by 35 cycles of $30 \mathrm{~s}$ at $94^{\circ} \mathrm{C}, 30 \mathrm{~s}$ at $36^{\circ} \mathrm{C}, 30 \mathrm{~s}$ at $72^{\circ} \mathrm{C}$, and a final elongation cycle of $10 \mathrm{~min}$ at $72^{\circ} \mathrm{C}$. Ramp times were $0.6^{\circ} \mathrm{C} \mathrm{s}^{-1}$. Amplification products were resolved by agarose gel electrophoresis $(1.5 \%)$ in TBE buffer $(45 \mathrm{mM}$ Tris Borate, $1 \mathrm{mM}$ EDTA) and visualised uner UV light after ethidium bromide staining.

One hundred 10-mer primers (Operon Technologies Inc., California, Kits A, K, L, $M, N)$ were initially screened for amplifica- tion with Gelidium sesquipedale DNA. Those that did not show positive amplifications were immediately rejected. Each time a new population was analysed, primer reproducibility was tested by including a previously analysed population in the new run. Banding patterns of this population obtained at different occasions were compared. If the pattern was different the primer was considered non-reproducible, and therefore discarded.

A presence/absence data matrix of clearly defined bands produced by each primer was generated. Pairwise similarities (S) were calculated using both the simple matching coefficient (Sneath \& Sokal 1973), number of all matches (including the number of absent bands in common) divided by the total number of bands, and the Dice coefficient (Dice 1945, Sneath \& Sokal 1973), 2 times the bands shared by 2 samples, divided by the number of bands displayed by each sample. The first coefficient considers both the presence and the absence of bands to calculate similarity between samples while the second uses only the presence of bands. Pairwise similarities were converted into pairwise distances (1-S). Both coefficients revealed identical distance patterns. The Dice coefficient was chosen for all subsequent analyses. A multidimensional scaling analysis of the distance matrix was performed to reveal the relative genetic distance of populations in a space of 2 dimensions (Statistica package). A distance tree was constructed using the neighbour-joining method (Saitou \& Nei 1987) of the program Distan 6.01 (Klerk \& Stam unpubl.). Bootstrap analysis was done to test for tree reliability.

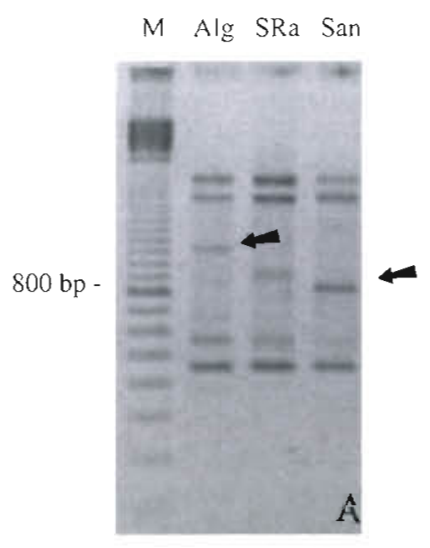

Fig. 3. RAPD amplifications of the following Gelidium sesquipedale populations, using primer OPL16: Alg: Algeciras, SRa: São Rafael, San: Santander, Cas: Casablanca, Ken: Kenitra, Ing: Ingrina, Ode: Odeceixe, SMa: Sào Martinho, Bil: Bilbao. The arrows show polymorphic markers specific for Algeciras and Santander. Polymorphism reproducibility is observed between gel $\mathrm{A}$ and $\mathrm{B}$ for the Santander lane
M Cas Ken SRa Ing Ode SMa San Bil

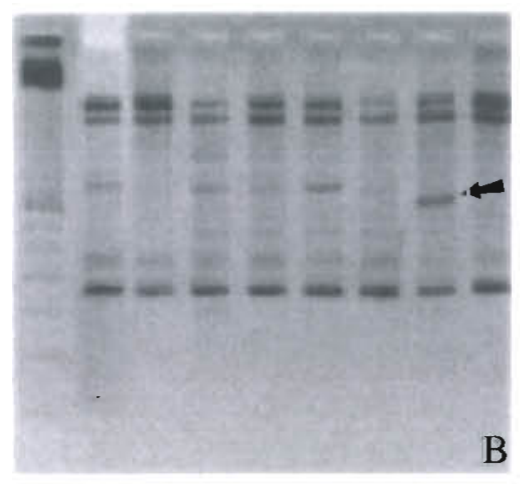


Table 1. Pairwise distance matrix among the 5 bulk samples collected in the Gelidium sesquipedale Espichel population Distances were calculated as 1-Dice similarity

\begin{tabular}{|lcccc|}
\hline & Bulk 1 & Bulk 2 & Bulk 3 & Bulk 4 \\
\hline Bulk 1 & & & & \\
Bulk 2 & 0.062 & & & \\
Bulk 3 & 0.042 & 0.061 & & \\
Bulk 4 & 0.094 & 0.086 & 0.083 & \\
Bulk 5 & 0.060 & 0.079 & 0.033 & 0.056 \\
\hline
\end{tabular}

The correlation between genetic distance and geographic distance matrices was tested using the Mantel test (Mantel 1967) of the Genetix package (Belkhir et al. 1996-1998). This non-parametric test allows rejecting or retaining the null hypothesis that matrices are independent.

\section{RESULTS}

To assess the intrapopulation bulk variability, 18 primers were selected that generated 134 scorable bands. Seventeen primers were selected for interpopulation analysis, which generated 200 scorable bands. Only $22.3 \%$ of the bands of the intrapopulation analysis were polymorphic in contrast to the interpopulation analysis, where $71.5 \%$ of the bands were polymorphic. Fig. 2 illustrates RAPD amplifications of the 5 bulk samples from Espichel, using 8 primers. No variability was found among unambiguous bands when using these primers. Interpopulation amplifications using primer OPL16 are shown in Fig. 3. An example of reproducibility of a polymorphic band is evident between San lanes (Santander) of Fig. 3A,B.
Table 3. List of RAPD specific markers of Gelidium sesquipedale populations. Each marker was screened to reproducibility

\begin{tabular}{|llc|}
\hline Population & Primer & Base pair \\
\hline Săo Rafael & OPL1 & 500 \\
& OPL3 & 2100 \\
& OPL3 & 2000 \\
& OPL3 & 800 \\
& OPL11 & 1800 \\
& OPL13 & 900 \\
Algeciras & OPL3 & 450 \\
& OPL3 & 350 \\
& OPL11 & 800 \\
Espichel & OPL16 & 1100 \\
& OPL3 & 1200 \\
Bilbao & OPL13 & 1800 \\
& OPA19 & 450 \\
Santander & OPL3 & 750 \\
Ingrina & OPL8 & 580 \\
Peniche & OPL16 & 800 \\
Viana do Castelo & OPA19 & 400 \\
& OPL1 & 750 \\
& OPL1 & 1800 \\
\hline
\end{tabular}

Genetic distances among the 5 bulk samples collected at Espichel population (Table 1) were much lower than those among geographically separated populations (Table 2) The average distance among Espichel bulks was $(0.065 \pm 0.0196)$, significantly lower than the average distance among populations $(0.241 \pm 0.0426)$.

We were able to identify 18 markers that were specific for just 1 population (Table 3). An example of a population-specific marker is presented in Fig. $3 \mathrm{~A}, \mathrm{~B}$ for Santander (Lane San). The number of specific polymorphic markers for São Rafael (6) and for Algeciras (4) was much higher than the other populations (1 to 2).

Table 2. Matrix of Gelidium sesquipedale geographical $(\mathrm{km})$ (above diagonal) and genetic distances (D = 1-Dice similarity) (below diagonal) among populations. Populations are ordered from south to north: Cas: Casablanca, Ken: Kenitra, Alg: Algeciras, SRa: Saa Rafael, Ing: Ingrina, Ode: Odeceixe, Esp: Espichei, Pen: Feniche, SMa: São Martinho, VCa: Viana do Castelo, San: Santander, Ara: Aramar, Bil: Bilbao, Ros: Roscoff

\begin{tabular}{|c|c|c|c|c|c|c|c|c|c|c|c|c|c|c|}
\hline & Cas & Ken & Alg & $\mathrm{SRa}$ & Ing & Ode & Esp & Pen & SMa & $\mathrm{VCA}$ & San & Ara & Bil & Ros \\
\hline Cas & - & 125 & 375 & 557 & 612 & 672 & 788 & 899 & 926 & 1170 & 1623 & 1805 & 1876 & 2536 \\
\hline Ken & 0.161 & - & 250 & 532 & 587 & 647 & 763 & 874 & 900 & 1145 & 1598 & 1780 & 1851. & 2511 \\
\hline Alg & 0.209 & 0.243 & - & 300 & 355 & 415 & 541 & 642 & 669 & 913 & 1366 & 1548 & 1619 & 2279 \\
\hline $\mathrm{SRa}$ & 0.265 & 0.290 & 0.285 & - & 55 & 115 & 231 & 342 & 369 & 613 & 1066 & 1248 & 1319 & 1979 \\
\hline Ing & 0.209 & 0.224 & 0.253 & 0.200 & - & 60 & 175 & 286 & 313 & 557 & 1010 & 1192 & 1263 & 1923 \\
\hline Ode & 0.184 & 0.144 & 0.234 & 0.259 & 0.149 & - & 115 & 227 & 253 & 497 & 950 & 1132 & 1204 & 1864 \\
\hline$E s p$ & 0.246 & 0.238 & 0.278 & 0.237 & 0.237 & 0.167 & - & 111 & 138 & 382 & 835 & 1017 & 1088 & 1748 \\
\hline Pen & 0.246 & 0.249 & 0.245 & 0.196 & 0.192 & 0.177 & 0.167 & - & 27 & 271 & 723 & 905 & 977 & 1637 \\
\hline SMa & 0.203 & 0.206 & 0.270 & 0.215 & 0.183 & 0.154 & 0.231 & 0.133 & - & 244 & 697 & 879 & 950 & 1610 \\
\hline $\mathrm{VCa}$ & 0.221 & 0.223 & 0.262 & 0.202 & 0.177 & 0.173 & 0.204 & 0.123 & 0.129 & - & 453 & 635 & 706 & 1366 \\
\hline San & 0.212 & 0.193 & 0.311 & 0.290 & 0.236 & 0.272 & 0.295 & 0.249 & 0.241 & 0.268 & - & 182 & 253 & 913 \\
\hline Ara & 0.209 & 0.179 & 0.282 & 0.296 & 0.289 & 0.223 & 0.301 & 0.245 & 0.213 & 0.24 & 0.158 & - & 71 & 731. \\
\hline Bil & 0.178 & 0.169 & 0.263 & 0.299 & 0.223 & 0.203 & 0.259 & 0.236 & 0.193 & 0.243 & 0.148 & 0.115 & - & 660 \\
\hline Ros & 0.213 & 0.183 & 0.303 & 0.340 & 0.252 & 0.207 & 0.275 & 0.252 & 0.209 & 0.259 & 0.161 & 0.117 & 0.116 & - \\
\hline
\end{tabular}




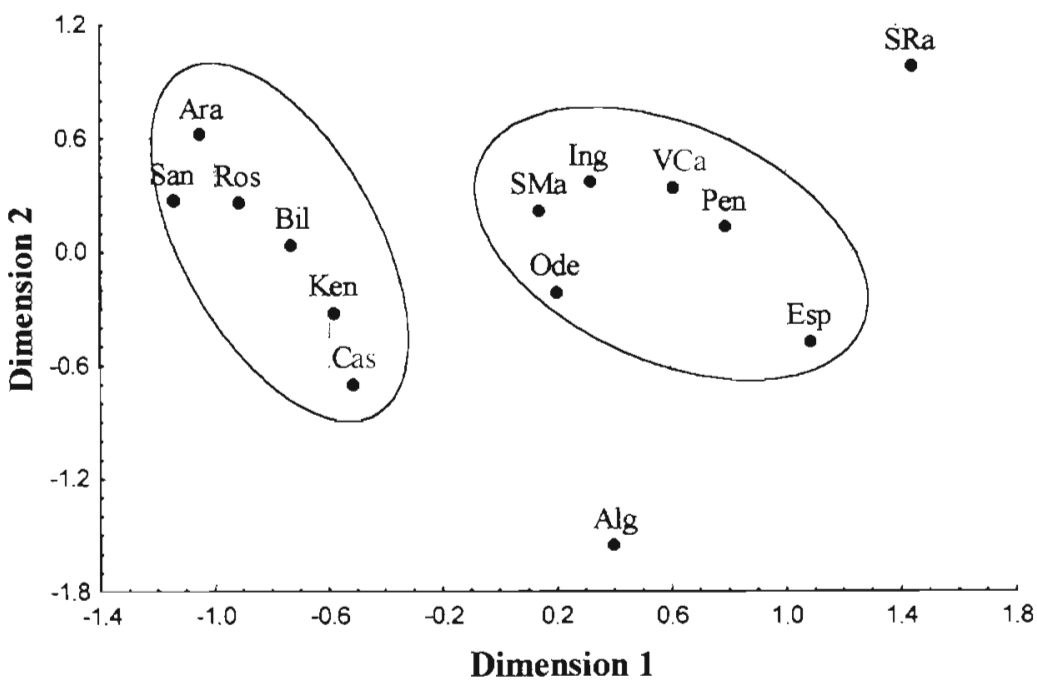

Fig. 4. Two-dimensional representation of multidimensional scaling analysis of the genetic distance matrix of Gelidium sesquipedale. Two groups of populations are evident (see text). Algeciras and Sào Rafael appear isolated. See Fig. 1 for population location abbreviations

This may be an indication of a low gene flow between these populations and their neighbours. Their relative isolation is also apparent when the distance matrix is analysed by multidimensional scaling (Fig. 4). This analysis made evident 2 main groups of populations: one including all the Portuguese populations except São Rafael, and the other including the populations of northern Spain, of France, and of Morocco.

Neighbour-joining analysis of the interpopulation distance matrix (Fig. 5) discriminated a northern group that includes the Gelidium sesquipedale populations from northern Spain, Aramar, Santander and Bilbao, and the population of Roscoff in France. This branch is supported by a high bootstrap value (98\%), suggesting a clear genetic separation. Another group, which lay south from the above and contained populations from northern Portugal, Viana do Castelo, São Martinho and Peniche, also emerged, but was not as well supported by bootstrap analysis (85\%).

RAPD genetic distances among Gelidium sesquipedale populations over the species geographic distribution showed a significant (Mantel test, $\mathrm{p}=0.024$ ) positive correlation with geographic distances among populations (Fig, 6).

\section{DISCUSSION}

Low genetic distances among bulks within the Espichel population, in relation to genetic distances of geographically separated populations, suggest that a single bulk may represent each population. Yu \& Pauls (1993) showed that the RAPD patterns obtained from bulk DNA samples represent the most common markers of the individuals mixed in the bulk. Markers that are only present in a few individuals do not amplify, because they represent a small proportion of the template in the mixture, when compared to markers common to most individuals. This methodology only reveals well-conserved population markers, reducing faint bands and non-reproducible bands. This may be an advantage because faint bands contribute more to scoring error, hiding the RAPDs signal at short geographical scales (van Oppen et al. 1996).

Results showed that the lowest RAPD distances were found among northern populations, ranging from 0.115 to 0.161 (Table 2), suggesting higher gene flow within populations. This was evident not only among populations of the northern group, Aramar, Santander, Bilbao and Roscoff, but also among populations of northern Portugal, Viana do Castelo, São Martinho and Peniche (0.123 to $0.133)$. An explanation for this may be the fact that

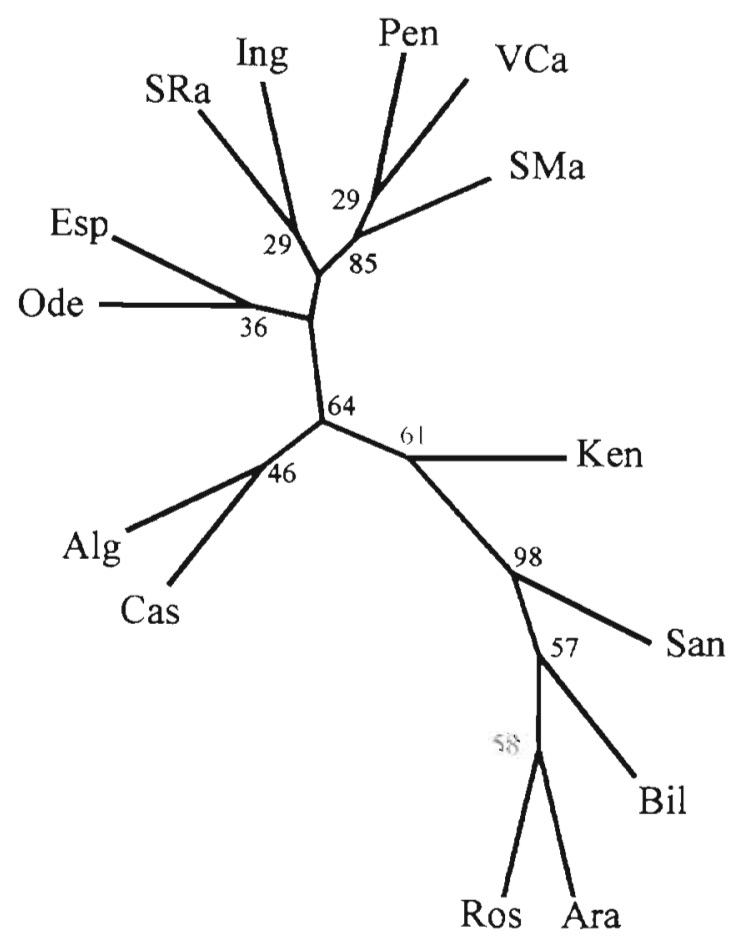

Fig. 5. Neighbor-joining distance tree of Gelidium sesquipedale populations. Numbers represent bootstrap values for each branch (100 replicates). See Fig. 1 for population location abbreviations 

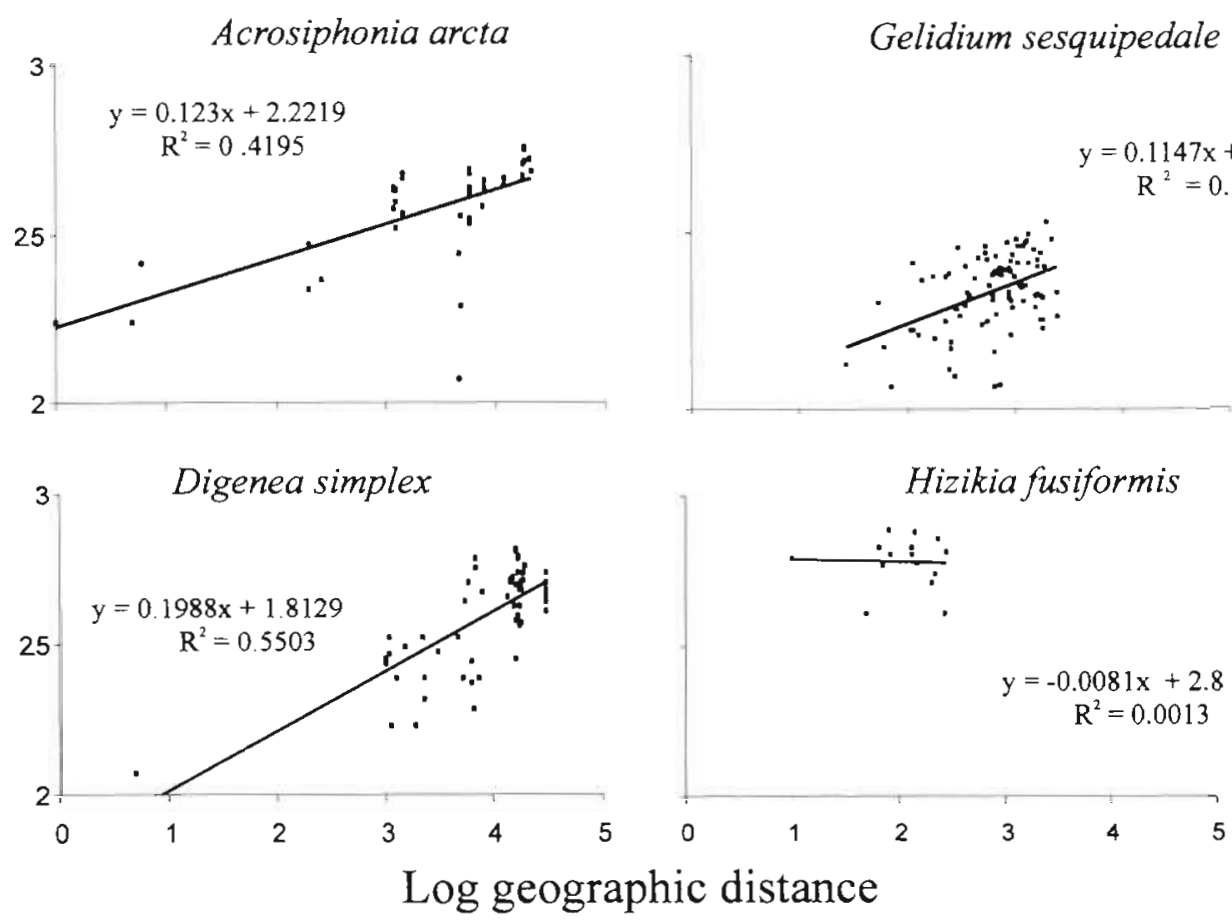

\section{Gelidium sesquipedale}

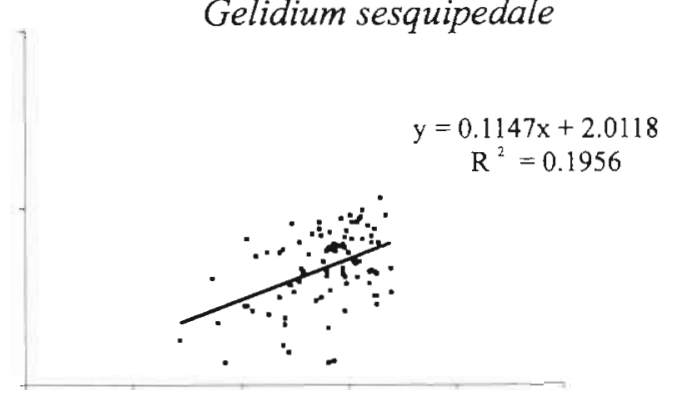

Fig. 6. Relationships between geographic and genetic distances among populations of 4 seaweed species, Gelidiu sesquipedale (this work), Digenea simplex (Pakker et al. 1996), Acrosiphonia arcta (van Oppen et al. 1994) and Hizikia fusiformis (Park et al. 1998) Mantel test was used to test for significant correlations between geographical and genetic distances (see text) northern coasts are generally more stormy than southern ones, resulting in higher quantities of broken fronds in the water which may be transported to reattach in new locations. The dispersal strategies of Gelidium species rely more on the transport and reattachment of loose fronds than on spore dispersal. Gelidium spores do not disperse over long distances and have the strongest capacity for attachment immediately after shedding (Santelices 1990). On the other hand, the capacity of loose fronds of $G$. sesquipedale to re-attach to calcareous substrates, by production of rhizoidal clusters, has been well documented (Juanes \& Puente 1993, Salinas \& Valdés 1993). In addition, broken fronds can be fertile and shed their spores in new sites. Early work of Seoane-Camba (1969) in northern Spain showed both that the number of storm. tossed fronds of $G$. sesquipedale increased towards autumn, after stormy periods, and that more fertile fronds were found in tossed fronds than in the populations that remained attached.

Near-shore surface circulation along the Atlantic coastline of Europe is poorly defined, but there is evidence of both southward and northward flows. The upwelling events associated with the summer trade winds along the Portuguese coast result in a geostrophic adjustment that induces a southward circulation (Haynes et al. 1993). An example of seaweed transportation during summer was the presence of Himanthalja elongata receptacle blades at the southwest coast of Portugal (Santos pers. obs.). This locality lies a few hundred kilometres south of the southern limit of the species distribution, in northern Portugal (Ardré 1970). During the non-upwelling season, Frouin et al. (1990) and Haynes \& Barton (1990) observed a surface poleward flow along the shelf edge of the western Iberian Peninsula. This suggests that there is a potential for high dispersal of fronds up and down the west coast of. Portugal. Our results showed that genetic distances among Portuguese populations are generally lower than 0.2 , except São Rafael (Table 2). In particular, the $85 \%$ bootstrap value for the grouping of Portuguese northern populations, Viana do Castelo, São Martinho and Peniche (Fig. 5), indicates high gene flow among them. This close association is not evident in the 2-dimensional plot of multidimensional scaling analysis of Fig. 4, but is evident along the third dimension (data not shown) which isolates the 3 populations.

Relvas \& Barton (1996) observed a poleward flow along the continental shelf of the southern coast of Portugal around Cape São Vicente, in late spring, prior to upwelling. Upwelling events change the direction of this flow to toward the equator. The great mixing of water masses around Cape São Vicente may enhance the gene flow between Ingrina and Odeceixe. Ingrina, located along the southern coast is genetically more similar to Odeceixe, on the southwest coast than to São Rafael, located on the south coast near Ingrina (Fig. 1). Genetic distances among these populations showed the same similarity patterns when independently analysed elsewhere (Alberto et al. 1997). This is a good indication of the reproducibility of this methodology. 
More evidence of the relative isolation of the São Rafael population is given by the multidimensional analysis (Fig. 4) and by its high number of polymorphic markers (Table 3). The same arguments suggest that Algeciras is also isolated. This population is situated in the northwest Alboran Sea, where water circulation anticyclone gyres are well documented (Viúdez et al. 1996). This causes a physical barrier that restricts the gene flow between Mediterranean and Atlantic surface water masses, as it was documented for fishes and invertebrates (Saavedra et al. 1995, Borsa et al. 1997).

The neighbour-joining analysis among Gelidium sesquipedale populations separated the most northern populations (from northern Spain and northern France) from all the others. This isolation suggests that Cape Finisterra is an important geographical barrier between the west coast of Portugal and the northern coast of Spain, preventing a regular transport of $G$. sesquipedale fronds around the northwest corner of the Iberian Peninsula (Cape Finisterra). There is controversy concerning the near-shore surface currents in this area. Some authors postulate that the Iberian northward current connects to the Porcupine current, along the west Scottish coast (Haynes \& Barton 1990), whereas others show evidence that at least part of the current turns around Cape Finisterra (Haynes et al. 1993). However, the latter conclusion was based on the tracking of only 2 drifters from which only 1 turned around the cape. Model simulations developed by Neves et al. (1996) support this last hypothesis, contrary to our data which suggest that the long-term prevailing currents do not flow around Cape Finisterra. The use of seaweed genetic distances as biotracers of prevailing currents is advantageous because it integrates long-term patterns of water movement while many oceanographic observations are limited to single moorings or a few weeks of observations (Barton 1990).

The position of Moroccan populations in the multidimensional scaling plot (Fig, 4), lying closer to northern Spanish populations than to Portuguese populations, seems contradictory with both the geographical distances and the expected surface poleward flow along the coasts of northwest Africa and the western Iberian Peninsula (Barton 1990). It suggests that the transport of Gelidium sesquipedale from the Moroccan coast to the coast of Portugal is not frequent perhaps due to the long distance between them. The physical discontinuity where the Mediterranean outflow occurs further complicates the circulation between the northern Moroccan coast and the coast of Portugal.

To our knowledge, the correlation between genetic and geographical distances has not been tested in seaweed biogeographic studies. Fig. 6 compares the relationship between RAPD calculated genetic distance and geographical distance for Gelidium sesquipedale, with available data from Acrosiphonia arcta (van Oppen et al. 1994), Digenea simplex (Pakker et al. 1996) and Hizikia fusiformis (Park et al. 1998). A significant correlation was found for the first 3 species (Mantel test $p$-values, respectively, $p=0.024, p=$ 0.00799 and $\mathrm{p}=0.00499$ ), but not for $H$. fusiformis ( $\mathrm{p}=$ 0.658). The decreasing $p$-values (increasing significance of correlation) follow the increase of geographical scales assessed, $H$. fusiformis being the lowest geographical scale study. The use of RAPDs to assess the genetic relatedness among seaweed populations is probably restricted to geographical scales higher than this, as van Oppen at al. (1996) have pointed out.

Both Digenea simplex and Acrosiphonia arcta are ancestral species with disjunct populations distributed worldwide. The low genetic relatedness among their isolated groups of populations results from long geological time scale processes such as paleoclimatic change and continental drift, rather than 'short time' dispersal mechanisms. On the other hand, the significant positive correlation showed in the case of Gelidium sesquipedale is evidence that a continuous transport of detached fronds by prevailing currents and their reattachment to new substrate is an effective dispersal mechanism of the species, sustaining the gene flow among populations.

Acknowledgements. We are particularly indebted to the people who collected and sent samples of Gelidum sesquipedale from various locations: Abdeslam Erzini from Casablanca, A. Mouradi-Givernaud from Kenitra, Raquel Carmona and Xavier Niell from Algeciras, José Rico and Ricardo Melo from Aramar, José Juanes from Santander, José Gorostiaga from Bilbao and Philippe Potin from Roscoff. This work would not have been possible without their contribution. We thank Paulo Relvas for enlightening discussions on ocean circulation.

\section{LITERATURE CITED}

Alberto F, Santos R, Leitāo J (1997) DNA extraction and RAPD markers to assess the genetic similarity among Gelidium sesquipedale (Rhodophyta) populations. J Phycol 33: $706-710$

Ardré F (1970) Contribution à l'étude des algues marines du Portugal. I. La flore. Port Acta Biol 10:1-423

Barton ED (1990) The poleward undercurrent on the eastern boundary of the subtropical north Atlantic. In: Neshyba SJ, Mooers ChNK, Smith RL, Barber RT (eds) Poleward flows along eastern ocean boundaries. Springer-Verlag, New York, p 82-92

Belkhir K, Borsa P, Goodet, Chikhi L, Bonhomme F, (1996-1998) GENETIX, logicel sous WINDOWS TM pour la génétique des populations. Laboratoire Génome et populations, CNRS VPR 9060. Université de Montpellier II, Montpellier

Borsa P. Naciri M, Bahri L, Chikhi L, Garcia de Leon FJ, Kotoulas G (1997) Infraspecific zoogeography of the Mediterranean: population genetic analysis on sixteen 
Atlanto-Mediterranean species (fishes and invertebrates). Vie Milieu 4:295-305

Bucklin A, Rienecker MM, Mooers CNK (1989) Genetic tracers of zooplankton transport in coastal filaments off northern California. J Geophys Res 94:8277-8288

Cover JA, Olsen JL, Stam WT (1997) Genetic variability and spatial separation in the sea palm kelp Postelsia palmaeformis (Phaeophyceae) as assessed with M13 fingerprints and RAPDs. J Phycol 33:561-568

Dice JR (1945) Measures of the amount of ecological association between species. Ecology 26:164-166

Dixon PS, Irvine LM (1977) Seaweeds of the British Isles. Vol 1 Rhodophyta. Part 1. Introduction, Nemaliales and Gigartinales. British Museum (Natural History), London

Dutcher JA, Kapraun DF (1994) Random polymorphic DNA (RAPD) identification of genetic variation in three species of Porphyra (Bangiales, Rhodophyta). J Appl Phycol 6: $267-273$

Frouin R, Fiuza AFG, Ambar I, Boyd TJ (1990) Observations of a poleward surface current off the coasts of Portugal and Spain during winter. J Geophys Res 95:679-691.

Gonzalez M, Montoya R, Candia A, Gomez P, Cisternas M (1996) Organellar DNA restriction fragment length polymorphism (RFLP) and nuclear random amplified polymorphic DNA (RAPD) analyses of morphotypes of Gracilaria (Gracilariales, Rhodophyta) from Chile. Hydrobiologia 326-327:229-234

Haynes R, Barton D (1990) A poleward flow along the Atlantic coast of the Iberian Peninsula. J Geophys Res 95: $11425-11442$

Haynes R, Barton D, Pilling I (1993) Development, persistence, and variability of upwelling filaments off the Atlantic coast of the Iberian Peninsula. J Geophys Res 12: 22681-22692

Ho C, Phang S, Pang T (1995) Molecular characterisation of Sargassum polycystum and S. siliquosum (Phaeophyta) by polymerase chain reaction (PCR) using random amplified polymorphic DNA. (RAPD) primers. J Appl Phycol 7:33-41

Juanes JA, Borja A (1991) Biological criteria for the exploitation of the commercially important species of Gelidium in Spain. Hydrobiologia 22 1:45-54

Juanes JA, Puente A (1993) Differential reattachment capacity of isomorphic life history phases of Gelidium sesquipedale. Hydrobiologia 260/261:139-144

Mantel N (1967) The detection of disease clustering and generalised regression approach. Cancer Res 27:209-220

Melo R (1998) Gelidium commercial exploitation: natural resources and cultivation. J Appi Phycol 10:303-314

Meneses I (1996) Assessment of populations of Gracilaria chilensis (Gracilariales, Rhodophyta) utilising RAPDs. J Appl Phycol 8:185-192

Michelmore RW Paran I. Kesseli RV (1991) Identification of markers linked to disease-resistance genes by bulked segregant analysis: a rapid method to detect markers in specific genomic regions by using segregating populations. Proc Natl Acad Sci USA 88:9828-9832

Neves RJ, Coelho HS, Leitão PC, Santos AJ (1996) Numerical modelling of North Atlantic eastern boundary current system, Ocean Margin Exchange (OMEX). Final report. Université Libre de Bruxelles, Brussels, p 517-536

Pakker $\mathrm{H}$, Klerk $\mathrm{H}$, Van Campen $\mathrm{JH}$, Olsen JL, Breeman AM (1996) Evolutionary and ecological differentiation in the pantropical to warm temperate seaweed Digenea simplex (Rhodophyta). J Phycol 32:250-257

Park JW, Cho YC, Nam B. Jin H, Sohn CH, Hong Y (1998)
RAPD identification of genetic variation in seaweed Hizikia fusiformis (Fucales, Phaeophyta). J Mar Biotechnol 6:62-74

Patwary MU, van der Meer JP (1994) Application of RAPD markers in a examination of heterosis in Gelidium vagum (Rhodophyta). J Phycol 30:91-97

Patwary MU, MCKay RM, van der Meer JP (1993) Revealing genetic markers in Gelidium vagum (Rhodophyta) through the random amplified polymorphic DNA (RAPD) technique. J Phycol 29:216-222

Relvas P, Barton ED (1996) Poseidon cruse $201 / 9$ report: Acoustic Doppler current profiler data-velocity fields. University of Algarve, Faro

Saavedra C, Zapata C, Alvarez G (1995) Geographical patterns of variability at allozyme loci in the European Ostrea edulis. Mar Biol 122:95-104

Saitou N, Nei M (1987) The neighbour-joining method: a new method for reconstructing phylogenetic trees. Mol Biol Evol 4:406-425

Salinas JM, Valdés L (1993) Influence of temperature and photoperiod on the re-attachment process of Gelidium sesquipedale (Clem.) Born. et Thur. (Gelidiales, Rhodophyta). J Appl Phycol 5:317-326

Sambrook J, Fritch EF, Maniatis T (1989) Molecular cloning: a laboratory manual, Vol 2, 2nd edn. Cold Spring Harbour Laboratory Press, Plainview, NY

Santelices B (1990) Patterns of reproduction, dispersal and recruitment in seaweeds. Oceanogr Mar Biol Annu Rev 28:177-276

Santos R, Duarte P (1991) Marine plant harvest in Portugal. J Appl Phycol 3:11-18

Seoane-Camba J (1969) Crecimiento, producción y desprendimiento de biomassa en Gelidium sesquipedale (Clem.) Thuret. Proc Int Seaweed Symp 6:365-374

Sneath PH, Sokal RR (1973) Numerical taxonomy. Freeman, San Francisco

Stoehr S, Hagen E, John HCh, Mittelstaedt E, Schulz K, Vanicek M, Weikert $H$ (1997) Poleward plankton transport along the Moroccan and Iberian continental slope. Ber Biol Anst Helgol 12:1-53

van Oppen $\mathrm{MJH}$, Diekmann OE, Wiencke C, Stam WT, Olsen JL (1994) Tracking dispersal routes: phylogeography of the Arctic Antarctic disjunct seaweed Acrosiphonia arcta (Chlorophyta). J Phycol 30:67-80

van Oppen MJH, Klerk $H_{1}$ de Graaf $M$, Stam WT, Olsen JL (1996) Assessing the limits of random amplified polymorphic DNAs (RA.PDs) in seaweed biogeography. J Phycol $32: 433-444$

Viúdez A, Tintoré J, Haney RL (1996) Circulation in the Alboran sea as determined by quasi-synoptic hydrographic observations. Part I: Three-dimensional structure of the two anticyclonic gryres. J Phys Oceanogr 26:684-705

Weising K, Nybom H, Wolff K, Meyer W (1995) DNA fingerprinting in plants and fungi. CRC Press, London

Welsh J, McClelland M (1990) Fingerprinting genomes using PCR with arbitrary primers. Nucleic Acids Res 18 $7213-7218$

Williams JGK, Kubelik AR, Livak KJ, Rafalski JÁ, Tingey S (1990) DNA polymorphisms amplified by arbitrary primers are useful as genetic markers. Nucleic Acids Res 18 $6531-6535$

Yu K, Pauls KP (1993) Rapid estimation of genetic relatedness among populations of alfalfa by random amplification of bulked genomic DNA samples. Theor Appl Genet 86 : $788-794$

Submitted: February 15, 1999; Accepted: August 3, 1999

Proofs received from author(s): December 16, 1999 